DOI 10.18551/rjoas.2021-05.22

\title{
FACTORS INFLUENCING SOCIAL MEDIA UTILIZATION BY TOURISM VILLAGE ACTORS AT CIAMPEA SUBDISTRICT, BOGOR REGENCY OF INDONESIA
}

\author{
Santoso Hudi, Doctoral Student \\ Study Program of Development Communication, Faculty of Human Ecology, \\ Bogor Agricultural University \& Study Program of Comunication, Vocational School, \\ IPB University, Indonesia
}

\author{
Saleh Amiruddin \\ Department of Communication and Community Development, Faculty of Human Ecology, \\ IPB University, Indonesia
}

Hubeis Musa

Department of Management, Faculty of Economy and Management, IPB University, Indonesia

Priatna Wahyu Budi

Department of Agribusiness, Faculty of Economy and Management, IPB University, Indonesia

*E-mail: hudi.santoso@apps.ipb.ac.id

\begin{abstract}
Increasing the capacity of tourism village actors does not only rely on the use of social media and marketing communications but also takes advantage of other factors such as internal, external, and environmental factors. This study aims to identify the level of media utilization by tourism village actors and to analyze the factors that utilize social media by tourism village actors in Bogor Regency. The study approach used was quantitative data with a survey method and a questionnaire as a data collection tool. The sample of this study was 30 tourism village actors from two villages in Ciampea Subdistrict, namely Cihideung Udik and Tegal Waru villages. The data were collected in February 2020. Data were analyzed descriptively using SPSS 24 and inferential using PLS 3. The results showed that the level of social media utilization by tourism actors in Bogor Regency was in a low category $(80,0$ percent), especially on social media YouTube. In addition, the ability of tourism actors in utilizing Instagram media was also in the low category (56,7 percent). This result indicates that tourism actors do not yet understand managing creative procedures, creating interesting content such as photos and videos on YouTube and Instagram. Factors that influence the use of social media by tourism village actors in Bogor Regency are internal, external, and environmental factors. Internal factors are motivation and informal education of tourism village actors, external factors are the role of community leaders and universities, while environmental factors are physical facilities, tourism institutions, and economy.
\end{abstract}

\section{KEY WORDS}

Factors, tourism village actors, use of social media.

The prospect of tourism at the international level as well as in Indonesia, especially in rural areas, so that it can be implemented, tourism actors should carry out careful and focused planning. This is to answer challenges and seize opportunities in the era of globalization/ digitalization through repositioning the existence of tourism activities starting from the investment, promotion, manufacturing of tourism products, preparing international marketing networks, preparing quality human resources (HR) through quality hospitality and tourism education. The use of internet technology (reservation system) to increase the 
number of tourist arrivals, and creating an atmosphere of coopetition (cooperation and competition) in internal and external levels (neighboring countries) (Hubeis 2018).

Increasing the capacity of tourism village actors is not only influenced by the use of social media and marketing communications but is also influenced by other factors such as internal factors, external factors, and environmental factors. Internal factors come from within the individual who deals with all aspects of life and the environment. External factors in this study are seen from supporting factors that come from outside the individual in the form of government support, community leaders, universities, and NGOs. Environmental factors that are thought to affect the capacity of tourism village actors in the use of social media, namely the physical environment, tourism institutions, and economic enterprises.

Based on the problems formulated above, the study was aimed to identify the level of social media utilization by tourism village actors and to analyze the factors that influence the use of social media by tourism village actors in Bogor Regency.

\section{METHODS OF RESEARCH}

The study was conducted in Bogor Regency as one of the areas with potentially built to become a tourism village. The choice of study location was carried out deliberately due to the location has a place and tourist attraction, and highly potential to be developed as tourism village, namely Cihideung Udik and Tegal Waru villages in Ciampea Subdistrict. Data collection was conducted in February 2020.

The number of samples was determined following Slovin provisions with a minimum limit of 30 respondents, thus in this study 30 respondents were taken from two villages in Ciampea District, Bogor Regency. Primary data obtained through survey results and field observations. Secondary data were collected from literature studies, related institutions such as the Bogor Regency Tourism Office.

The collected data were tabulated and analyzed using descriptive statistical tests, using the Statistical Product and Service Solution (SPSS) version 24 program, inferential statistical analysis using the Partial Least Square (PLS) 3 program. One-way hypothesis testing was carried out by looking at the significance level of the value. The path coefficient indicated by the t-statistic value must be above 1.64 for alpha 5 percent. (Abdillah and Jogiyanto 2015). Previously, a coefficient value above 0,7 was determined as requirement, therefore the bootstrapping process could be carried out to determine the level of significance (Sarwono and Narimawati 2015).

\section{RESULTS AND DISCUSSION}

Tourism village packaging collaborated with the use of technological innovation and social media can be an option and is expected to be a special attraction for the visitors of tourism villages. A successful tourism village will take advantage of existing technological advances, thus tourism village actors become more open and creative in utilizing social media as a means of promotion which is effective, efficient, flexible, and attractive amid the digitization of media content. The proper utilization of social media is very helpful in creating a positive impression of visitors about tourist attractions in the village. The selection of good communication media will also help marketing goals. Furthermore, the use of social media by actors in this tourism village can attract tourists from other areas to visit the tourism village destinations.

The use of social media also enhances personal, intelligent, creative, interactive, communication, and message approach, including empathy and emotion. Social media helps to present an attractive display of the content as a promotion for tourism village destinations to continue to attract visitors. (Királ'ová and Pavlíčeka, 2015). According to Subagio et al. (2008), capacity is a description of the ability of individuals or communities to face problems as part of their efforts to achieve sustainable development goals. Suprayitno (2011) adds that the level of capacity possessed is related to knowledge, attitudes, and abilities in overcoming 
various problems encountered by tourism actors in the form of technical, managerial, and social skills.

The capacity of tourism village actors in Bogor Regency in the utilization of social media YouTube was in a low category $(80,0$ percent). This shows that the management of tourism villages in Bogor Regency has not fully understood the procedures for making content, videos, which are persuasive in promoting tourism materials. This means that tourism actors have limited abilities regarding the use of YouTube media. Moreover, the ability of tourism actors to utilize Instagram media was in a low category (56,7 percent). This indicates that tourism actors do not understand how to manage, create creative content such as interesting photos and videos on Instagram. Social media such as Whatsapp, Facebook, Instagram, YouTube as internet-based applications have an important role in supporting the tourism industry in informing, promoting goals, destinations, tourism objects, travel costs, and accommodation. Apart from that, social media also helps tourists to search, organize, and share travel experiences. This platform can be used effectively to disseminate information to customers and the travel industry. (Amidi et al 2015).

Instagram is a new communication channel to promote tourism destinations in Indonesia. Instagram is a medium with many personal facilities that allow its users to upload what they see at tourism sites which makes it interesting to share. This happens because Instagram has advanced features as a photo and video editor (Fatanti and Suyadnya 2015). The way of thinking of tourism village actors is now beginning to open up with the presence of social media platforms. The use of social media and the ease of access has a positive impact seen from various aspects of life, either from the perspective of tourism village actors or the community. The percentage of social media utilization by tourism village actors can be seen in Table 1.

Table 1 - The percentage ofutilization of social media by tourism village actors

\begin{tabular}{lll}
\hline Variable & Category & Percentage \\
\hline Whatsapp & Very low & 6,7 \\
& Low & 13,3 \\
& High & 56,7 \\
Facebook & Very high & 23,3 \\
& Very low & 10,0 \\
& Low & 13,3 \\
Hnstagram & High & 40,0 \\
& Very high & 36,7 \\
& Very low & 0,0 \\
YouTube & Low & 56,7 \\
& High & 40,0 \\
& Very high & 3,3 \\
& Very low & 30,0 \\
& Low & 50,0 \\
& High & 20,0 \\
\hline
\end{tabular}

Note: $n=30$.

Tourism village actors in Bogor Regency need training and assistance in maximizing creative content. This is essential because of the ability or skills in designing, making creative, persuasive sentences about the attractiveness of a tourism village, thus YouTube and Instagram platforms are more accessible to the public and have a greater impact on tourist visits. According to Rathorea et al (2017), Social media is called the most innovative Internet-based application that allows users to produce content in various formats. Social media is a platform for sharing information from stakeholders who can exchange information and communicate among people or the community.Social media advertisements such as Instagram and YouTube, are designed for the interactivity of buyers and sellers as they facilitate real-time communication through interacting functions such as to reply, retweet, follow and comment (Tan et al 2018). According to Tan et al. (2018), advertising on social media is better and more interactive than conventional advertising used in marketing 
traditional tourism products such as television, radio, newspapers, magazines, billboards, flyers, catalogs, brochures, and leaflets. Therefore, the interactivity of tourism village actors with tourists has a significant positive relationship with the motivation of tourism actors to see and take advantage of advertisements on social media, Instagram, YouTube, and Facebook.

Evaluation of measurement and structural models carried out on the results of the Partial Least Square (PLS) analysis shows that the factors that influence the utilization of social media by tourism village actors in the Bogor Regency consist of internal, external, and environmental factors. Internal factors are reflected by non-formal education and motivation of tourism village actors. External factors are reflected in the roles of community leaders and universities. Environmental factors are reflected by physical facilities, tourism institutions, and the economy. The structural model equation of the factors that influence the utilization of social media by tourism village actors is: $Y_{1}=0,475 X_{1}+0,284 X_{2}-0.277+0,528$. The measurement model (outer model) is presented in Figure 1. While the structural model (inner model) is presented in Table 2 the significance value of the latent variable capacity of tourism actors in Bogor Regency. The $\mathrm{R}^{2}$ value of 0.472 indicates that 47 percent of the use of social media by tourism village actors is influenced by the factors examined in this study. Based on the $R^{2}$ value, the resulting model is in the moderate category. This refers to Sarwono and Narimawati (2015) that the $R^{2}$ value of endogenous latent variables is divided into four, namely 0.19 (weak); 0.33 (moderate); 0.67 (substantial), and > 0.7 (strong).

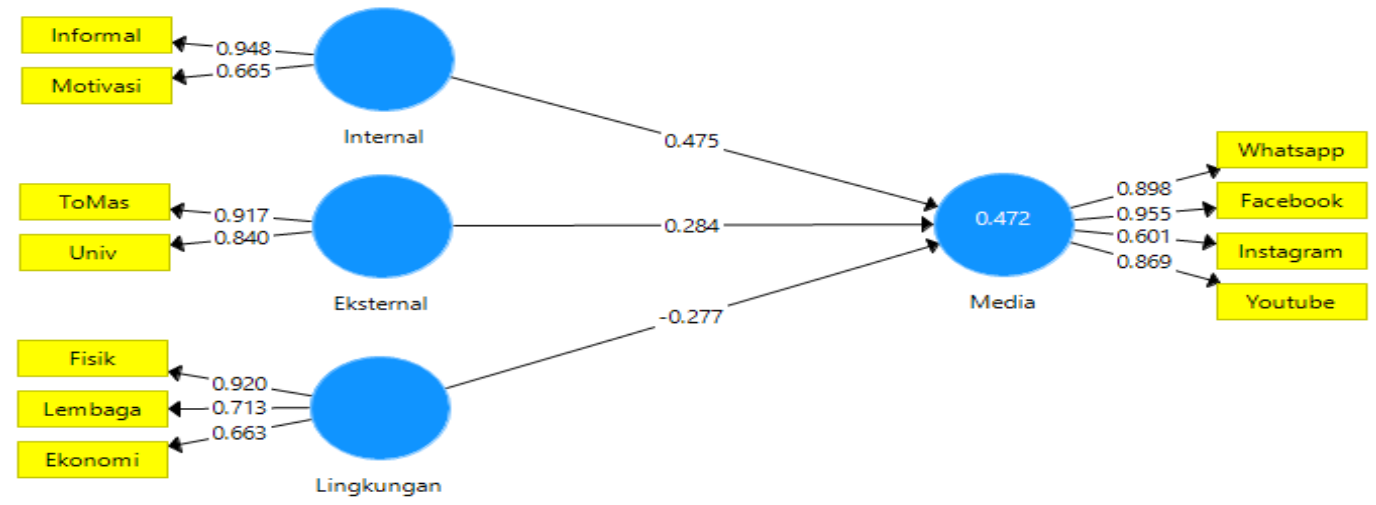

Figure 1 - The measurement model

Table 2 - The significance values of the latent variables on social media utilization by tourism village actors

\begin{tabular}{lllll}
\hline No & Matrix influence latent variables & Path coefficient & T-calculated & Significance \\
\hline 1 & Internal factor $(\mathrm{X} 1)=>$ Media $(\mathrm{Y} 1)$ & 0.475 & 3.692 & Significance \\
2 & External factor $(\mathrm{X} 2)=>$ Capacity $(\mathrm{Y} 1)$ & 0.284 & 1.711 & Significance \\
3 & Enviromental factor $(\mathrm{X} 3)=>$ Media $(\mathrm{Y} 1)$ & -0.277 & 1.520 & Significance \\
\hline
\end{tabular}

Note: value of $t$-calculated $>$ value of $t$-table $(1.64)=$ significance, $\alpha=5$ percent .

In this study, social media utilization by tourism village actors is reflected in Whatsapp, Facebook, Instagram, and YouTube. This is because these four aspects fulfill the factor loading requirements above 0,5 . Internal factors have a positive and direct significant effect on the use of social media by tourism village actors. Internal factors are reflected in the motivation and non-formal education of tourism village actors. Tourism actors need motivation in carrying out tourism businesses in the village; it can be desires and conscious goals which directed toward self-improvement and development.

Managanta (2018) stated that motivation will be directed at self, or one of the desires driven by others and by the environment, and can motivate others as well. The higher the education level of tourism village actors and the more they participate in training, the higher the capacity of tourism village managers/actors. Nurfitriana (2016) explained that the higher the non-formal education and formal education, the higher the level of one's capacity. 
Training is a level of non-formal education followed by tourism actors. Training attended by tourism village actors can affect capacity. The more often someone participates in training, the more knowledge they will gain and vice versa. According to Fatchiya (2010), a person's low capacity is influenced by low levels of non-formal education.

Tourism village managers in Bogor Regency frequently attend training held by the Tourism Office, NGOs, and University. The training provided is like how to optimize social media. Even so, the amount of training provided is rare because it is only once every three months and maybe never at all. However, if there is training, tourism actors are enthusiastic about participating in training activities. Another training that has been attended by tourism actors was carried out by the tourism office, namely training on the management of tourism objects as a tourist attraction, but training on ways to promote and market through social media, training on how to pack persuasive messages and training on the importance of changing mindsets in building villages for community economic empowerment has not been done by many related parties. The results obtained by the tourism village manager are being able to identify and see the village's potential as a source of village income. However, it has not yet reached the level of attracting visitors to visit tourist destinations that have an impact on the economic sector.

Tourism village actors have collaborated with village administrators and NGOs. However, they have not been able to innovate and collaborate with tourism activist groups (Kompepar), media activists, and tourism players from other developed and developing villages. Generally, many tourism village actors attended high school as the highest education level. At this level of education, it is easier for tourism actors to absorb the information conveyed than those who only graduate from elementary school or who do not receive any formal education. The information obtained can increase the knowledge of the tourism office, universities, NGOs so that the capacity of tourism village actors increases. This is in line with the study of Blaak et al. (2013) stated that non-formal education can be faster to meet the practical learning needs of the community because the curriculum and learning system can be more flexible and adaptable (according to the objectives of the learners/targets).

External factors positively and directly have a significant effect on social media utilization by tourism village actors. External factors are reflected by the role of community leaders and the University. The higher the role of community leaders, it can increase the capacity of tourism village actors. The results of Handayani's study (2008) showed that to change behavior or educate the public, it requires influence from community figures or community leaders. The role of community leaders is expected to support the capacity building of tourism village actors. This is because community leaders are one of the main sources of information. Apart from community leaders, the role of the Bogor Regency Tourism Office, private companies, and universities can help build the capacity of tourism village actors in Bogor Regency. Several universities have already assisted in creating and optimizing social media as media for tourism destination promotion and marketing, but there is a lack of assistance from related parties. Hariadi (2005) explained that the role of the government as a facilitator does not necessarily leave all matters to the community in the development aspect. Matters that are very strategic and part of public interest remain the obligation of the government. This is reinforced by Pramala's study (2018), explaining that higher education institutions have a big responsibility to contribute to managing affairs in solving various problems that exist in the community or society. Activities to increase the capacity of tourism village actors can be done if there is good coordination between the local government and the whole community. The government can act as a facilitator for the procurement of a number of goods donated or support in business legality, as well as support the availability of infrastructure.

Environmental factors have a direct positive significant effect on the use of social media by tourism village actors. Environmental factors are reflected by physical facilities, tourism institutions, and the economy. Physical facilities that are lacking, including road access to get to tourist sites, are not easy, apart from the many roads that are damaged and potholes in asphalt, making it difficult for tourists who want to visit tourism sites. In addition, 
uneven land contours and hilly locations as well as steep roads. On the other hand, tourists, especially local tourists, also play an important role in supporting the progress of village tourism. This must also be balanced by several supporting facilities as tourist attractions, such as lodging and outside and inside tourist area infrastructure. Infrastructure development requires a permit from the related agency and requires a large amount of money. Therefore until this day, the village is only able to provide simple facilities, such as toilets, prayer rooms, homestays, small stalls, and other facilities, fences, huts made of simple materials such as bamboo and wood. However, the attraction of this tourism village is Mount Salak, and views of Bogor city from above as well as many photo spots, available swimming pool facilities, and camping ground. It is expected that massive and targeted promotion and marketing on social media, will bring a good impact on tourist visits. In addition, the management is trying to target this tourist destination which is visited by many children as well as the younger generation who often visit tourism villages. The aspect of the beauty of tourist sites that are still maintained becomes a longing factor for tourists, especially tourists from other cities. Suprayitno (2018) explained that in planning a tourism area, tourist accommodation facilities should consider the conditions for centralizing accommodation. That is, the location of accommodation facilities is endeavored to be in the middle of adjacent to tourist attractions. Promotions that have been carried out on social media through several platforms, not only the tourism manager who has benefited, but also the local community may benefit from it as well. An example is the UKM (micro business) around the tourism village, especially the UKM Sari Sehat receives benefits because after the guests stay overnight or hold an event, they will automatically be advised to go there if they want to buy souvenirs such as plants, beverage ingredients, livestock seeds, souvenirs such as bags can be bought there. Vice versa, sometimes UKM visitors are also advised to visit tourist villages if they want to travel. Tourism institutions, such as the existence of a tourism activist group (Kompepar), are important in supporting tourism activities. Management of tourism villages becomes more optimal, especially in cooperation and collaboration between tourism villages, media activists, and also travel agents.

\section{CONCLUSION}

The level of social media utilization by tourism village actors in Bogor Regency was in a low category (80.0 percent), especially on social media YouTube. In addition, the ability of tourism actors to utilize Instagram media was also in the low category (56,7 percent). This shows that tourism managers do not understand how to manage, create creative content such as interesting photos and videos on YouTube and Instagram. The factors that influence social media utilization by tourism village actors in Bogor Regency are internal, external, and environmental factors. Internal factors that influence it are the motivation and informal education of tourism village actors, external factors that influence the role of community leaders and universities, while environmental factors affect physical facilities, tourism institutions, and the economy.

\section{SUGGESTIONS}

More intensive training and mentoring are urgently needed for tourism village actors in Bogor Regency to maximize creative content for promotion on social media from related parties, the Tourism Office, Universities, and NGOs. This is important because of the ability or skills in designing, making creative, persuasive sentences about the attractiveness of a tourism village, thus the Instagram platform is visited by more people and has an impact on tourist visits.

\section{CONFLICT OF INTEREST}

Authors declare that there is no conflict of interest whatsoever in the process of conducting current research. 


\section{ACKNOWLEDGEMENTS}

Acknowledgments the authors convey to the tourism village actors, who have recommended the author to conduct research in Bogor, West Java. Next, to the tourism village actors group in Bogor District, who have become respondents in this study. For their ooperation and assistance in answering questionnaire questions in order to complete the results of the study to complete this research, the authors say thank you.

\section{REFERENCES}

1. Abdillah W, Jogiyanto HM. (2015). PartialLeast Square (PLS), Alternatif Structural Equation Modeling (SEM) dalam Penelitian Bisnis.

2. Andi Amidi A, Yusmadi YJ, Shayesteh MD, Yuhanis A, Roghayeh S. (2015). "Review of Social Media Potential on Knowledge Sharing and Collaboration in Tourism Industry". Procedia Social and Behavioral Sciences 172, 120-125.

3. Blaak M, Openjuru GL, Zeelen J.(2013). "Non-formal vocational education in Uganda: Praktical empowerment throught a workable alternative". Journal of Educational Development. 33(13), 88-97.

4. Fatchiya A., (2010) "Pola Pengembangan Kapasitas Pembudidaya Ikan Kolam Air Tawar di Provinsi Jawa Barat". Disertasi. IPB. Bogor.

5. Fatanti MN. dan Suyadnya IW.(2015), "Beyond user gaze: How Instagram creates tourism destination brand", Procedia-Social and Behavioral Sciences 211, 1089- 1095.

6. Hariadi SS.(2005).Revitalisasi kelompok tani sebagai media penyuluhan pertanian di era globalisasi. Jurnal Ilmu-IImu Pertanian. 1(2), 83-93.

7. Handayani S. (2008).Partisipasi masyarakat kampung kota untuk meningkatkan kualitas lingkungan permukiman (Kasus: Permukiman Kampung Kota di Bandung). disertasi. Bogor (ID): Institut Pertanian Bogor.

8. Hubeis M. Tren Pariwisata. (2019). www.negerilaskarpelangi.com (2018) [diakses 23 November 2019].

9. Királ'ováa A, Pavlíčeka A.(2015).Development of Social Media Strategies in Tourism Destination. Procedia - Social and Behavioral Sciences 175, 358-366

10. Managanta AA.(2018)Kemandirian Petani dalam Meningkatkan Produktivitas Usahatani Kakao di Provinsi Sulawesi Tengah". [Disertasi]. Bogor (ID): Institut Pertanian Bogor.

11. Nurfitriana N. (2016). Perilaku Kewirausahaan Pelaku Usaha Pempek Skala Industri Mikro dan Kecil di Kota Palembang", Tesis. IPB. Bogor.

12. Pramala II.(2018).Peran institusi pendidikan tinggi dalam pengembangan kapasitas komunitas Desa Cibuntu dalam pengembangan pariwisata berbasis masyarakat", Jurnal Administrasi Pendidikan. 25(2), 275-293.

13. Rathorea A.K, Joshib U.C, Ilavarasanc P.V. (2017). Social Media Usage for Tourism: A Case of Rajasthan Tourism Information Technology and Quantitative Management", Procedia Computer Science 122, 751-75. 